\title{
Members Overseas
}

George H. (Turk) Bayly has been in Great Britain as a Pilot Officer with the R.C.A.F. since July, 1941 and after five months of intensive training is now on operations. He says that he finds his work extremely interesting but that details will have to wait until after the war.

His last letter home was written when he and his brother Jim, a Flight Sergeant Pilot, R.C.A.F., were on leave together at the home of their aunt near London. On the previous day, while walking down Oxford Street, he had met Oscar Larsen, formerly his boss at Kaninaskis, and they were plan. ning to have a day together before returning to their stations.

Cpl. Wm. A. MacNeill writes from England after two years' service with the Army Service Corps he has been transferred to the 20th Company Canadian Forestry Corps which is a unit from Saskatchewan.

F. O. Crossley, R.C.A.F., has been transferred from the Air Training School at Prince Albert to a station in Alberta.

Lieutenant M. A. Adamson, 14th Company, Canadian Forestry Corps, is stationed in the northern part of Scotland.

The camp is located in the midst of a splendid stand of pine and fir. There is a large plantation of Scotch pine about seventy-five years old, the trees in which run up to 24 inches in diameter. There is also Douglas fir, many of which are 3 feet in diameter.

The camp has its own generating unit so has all the electricity desired. It has installed its own mill for cutting lumber. In addition to sawn material they produce mine props and telephone poles. The Corps as a whole are cutting enough material to save about one boat load a day from Canada.

The camp is ideally located both for supplies and beauty of scenery. Thatched roof cottages, a beautiful old ivy-covered castle and extensive hea. ther covered moors are some of the interesting and lovely sights which make leisure hours a pleasure.

PROGRESS OF POST-WAR REHABILITATION COMMITTEE

Messrs. J. O. Wilson and Ellwood Wilson of the post-war rehabilitation committee held a meeting on May 29. W. G. Phipps, who was the third member of the committee appointed, has been forced to resign owing to pressure of work and the remaining members of the Committee have asked Professor G. G. Cosens to serve in his stead.

The two members of the Committee decided to solicit the support of Premier A. Godbout of Quebec and to ask the Central Committee on Rehabilitation to assign a definite position to the Society.

They also discussed details of putting men to work in forest colonies, in reforestation work on non-agricultural parts of established farms and in the building of fire lines which would be located so as to serve as haul roads either now or at a later date. The question of the Government providing wood using industries with funds, at a low interest rate, for the last-named project was also given consideration. 